\begin{tabular}{|l|l|l|l|l|l|}
\hline J. Tek. Ling & Vol. 12 & No. 1 & Hal. 25 - 34 & Jakarta, Januari 2011 & ISSN 1441-318X \\
\hline
\end{tabular}

\title{
PERKEMBANGAN TEKNOLOGI BATUBARA BERSIH BERWAWASAN LINGKUNGAN
}

\author{
Endang Suarna \\ Pusat Teknologi Pengembangan Sumberdaya Energi \\ Badan Pengkajian Penerapan Teknologi
}

\begin{abstract}
Coal has a very important role to meet energy demand in Indonesia, however, it is also the dirtiest fuel among the fossil fuels. As coal utilization continues to increase, pollutants and greenhouse gases emissions from the coal utilization also increase, that would lead to environmental problems. Therefore, development of clean coal technologies for reducing those emissions from coal utilization needs to be considered. The technologies are intended to reduce the policy conflict between continuing coal utilization and protecting environment potential by improving the effectiveness of control technologies and reducing their costs. In addition, the technologies have higher efficiency that would impact on conserving fuels that lead to reducing costs and extension of coal reserve availability.
\end{abstract}

Key words: coal, pollutants, greenhouse gases, technologies, costs

\section{PENDAHULUAN}

Batubara dikenal sebagai sumber energi atau bahan bakar fosil yang kotor, sehingga penggunaannya diperkirakan akan menyebabkan terjadinya pencemaran lingkungan. Namun semakin meningkatnya kebutuhan energi dan semakin terbatasnya cadangan minyak sebagai sumber energi utama, pemanfaatan batubara untuk memenuhi kebutuhan energi primer tersebut tidak dapat dielakan. Bahkan dalam delapan tahun terahir, peranan batubara sebagai sumber energi primer semakin meningkat, dari terbesar ke empat setelah minyak, biomasa, dan gas alam pada tahun 2000 , menjadi terbesar ke dua setelah minyak dari total pasokan energi primer tahun $2008{ }^{1}{ }^{1}$.

Pemanfaatan batubara sebagai sumber energi primer tersebut diperkirakan akan terus meningkat terutama untuk bahan bakar pembangkit listrik dan industri. Semakin meningkatnya penggunaan batubara tersebut diperkirakan akan menyebabkan semakin meningkat pula emisi polutan (bahan pencemar) seperti $\mathrm{SO}_{2}, \mathrm{NO}_{x}$, dan partikel yang dapat berdampak negatif terhadap lingkungan; serta emisi gas rumahkaca $\mathrm{CO}_{2}$ yang berdampak pada pemanasan global

Polutan-polutan tersebut dipersalahkan sebagai penyebab terjadinya kerusakan ekosistem yang berdampak bukan saja terhadap terganggunya kehidupan tumbuhan dan hewan, tetapi juga terganggunya kesehatan manusia. Sementara itu $\mathrm{CO}_{2}$ merupakan gas rumah kaca utama yang dipersalahkan sebagai penyebab terjadinya pemanasan global yang dapat berakibat pada terjadinya perubahan iklim. Dampak lebih 
lanjut dari pemanasan global tersebut adalah mencairnya es di kutub yang mengakibatkan naiknya permukaan laut yang berakibat terhadap berkurangnya daratan bahkan hilangnya pulau. Oleh karena itu dalam rangka optimalisasi pemanfaatan batubara dan mengurangi dampak lingkungan dari penggunaan batubara, pengembangan teknologi batubara bersih atau CCT (clean coal technologies) perlu dipertimbangkan.

Pengembangan teknologi batubara bersih tersebut ditujukan untuk mengurangi konflik kebijakan antara meneruskan penggunaan batubara dengan melindungi kualitas lingkungan melalui perbaikan efektivitas teknologi pengendalian dengan pengurangan biaya. Pendekatan dasar dari teknologi batubara bersih adalah mengurangi emisi polutan atau bahan pencemar seperti $\mathrm{SO}_{x}, \mathrm{NO}_{x}$, dan partikel debu.

Penerapan teknologi batubara bersih tersebut juga berguna untuk mengembangkan sistem termal yang lebih efisien, yaitu untuk memperoleh jumlah energi yang sama, diperlukan input batubara yang lebih sedikit, sehingga memperpanjang ketersediaan sumber daya energi lebih lama ${ }^{2}$. Berbagai macam teknologi batubara bersih masih sedang dalam pengembangan agar dapat menyediakan suatu metoda yang memuaskan secara lingkungan dalam penggunaan batubara terutama untuk pembangkit listrik. Teknologi-teknologi tersebut antara lain AFBC (atmospheric fluidized bed combustion), PFBC (pressurized fluidized bed combustion), FGD (flue-gas desulfurization), SCR (selective catalytic reduction), dan IGCC (integrated gasification combined cycle) ${ }^{3)}$.

\section{KEBUTUHAN ENERGI.}

Dalam waktu delapan tahun terahir, kebutuhan energi primer yang terdiri atas minyak mentah (crude oil), batubara, gas alam, tenaga air (hydropower), dan panas bumi (geothermal) di Indonesia dari tahun ke tahun meningkat terus dengan pertumbuhan rata-rata 3,31 persen setiap tahun, sehingga kebutuhan energi tersebut meningkat dari 0,99 milyar BOE (Barrel Oil Equivalent) pada tahun 2000 , menjadi 1,29 milyar $B O E$ pada tahun $2008^{1)}$ seperti digambarkan pada Gambar 1.

Sebagian besar dari kebutuhan energi primer tersebut dipasok oleh minyak, sedangkan sisanya dipenuhi oleh batubara, biomasa, gas alam, tenaga air, dan panas bumi. Minyak masih merupakan sumber energi primer yang utama, meskipun terjadi penurunan peranan (pangsa), yaitu dari 43,52 persen pada tahun 2000 , menjadi 35,25 persen pada tahun 2008 . Sebaliknya peranan batubara semakin meningkat, yaitu dari pangsa hanya 9,42 persen atau nomor empat terbesar setelah minyak, biomasa, dan gas alam pada tahun 2000, menjadi pangsa hampir 25 persen dari total kebutuhan energi primer atau nomor dua terbesar setelah minyak pada tahun $2008{ }^{1}$ ).

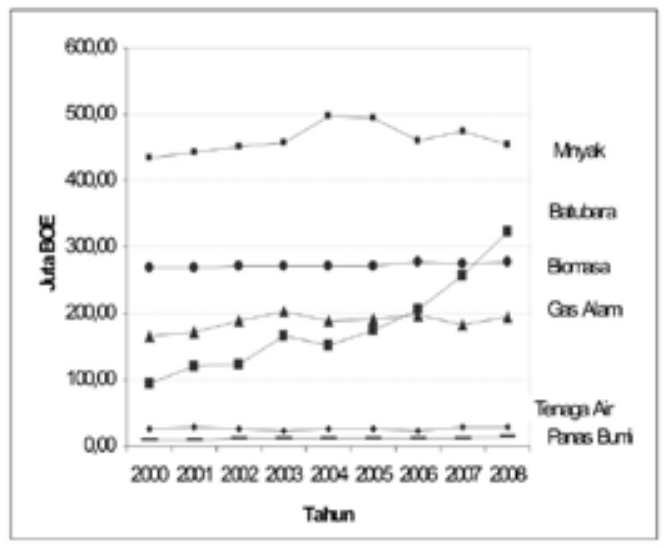

Sumber: ${ }^{11}$.

Gambar 1. Pasokan Energi Primer Menurut Sumber 2000-2008.

Berdasarkan penggunaan batubara dalam negeri, pembangkit listrik merupakan pengguna batubara yang utama, sedangkan sisanya dipergunakan untuk industri yang meliputi industri-industri semen dan keramik, besi dan baja, kertas \& pulp, dan industri lainnya yang meliputi industri-industri tekstil, gula, bata, dan genteng seperti 
diperlihatkan pada Gambar 2. Dalam delapan tahun terahir, yaitu dari tahun 2000 sampai dengan 2008 , penggunaan batubara di Indonesia, baik untuk pembangkit listrik maupun industri meningkat terus dengan pertumbuhan rata-rata lebih dari 15 persen per tahun, sehingga penggunaan batubara meningkat lebih dari tiga kali lipat dari 22,34 juta ton menjadi 69,11 juta ton. Penurunan peranan minyak dan peningkatan peranan batubara tersebut didorong oleh adanya program pengurangan minyak dengan memacu program diversifikasi energi oleh pemerintah untuk lebih menggunakan batubara dan gas terutama untuk sektor industri dan pembangkit listrik, karena cadangan minyak yang semakin terbatas.
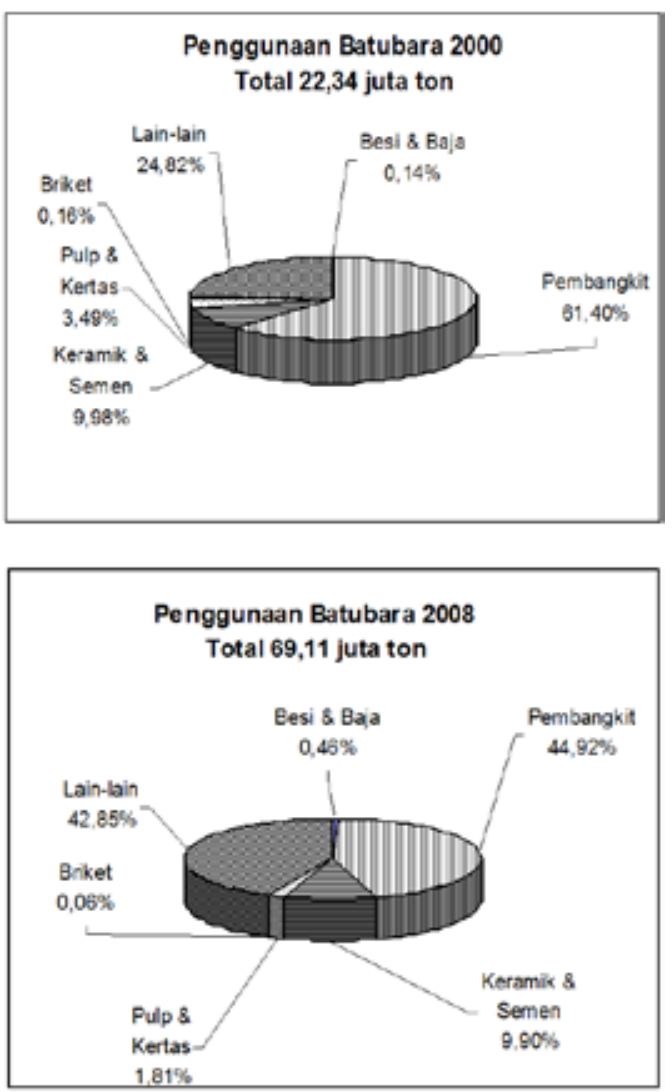

Sumber: ${ }^{1)}$.

Gambar 2. Penggunaan Batubara Domestik menurut Pengguna Tahun 2000 \& 2009
Penggunaan batubara untuk pembangkit listrik meningkat dengan pertumbuhan rata-rata hampir 11 persen per tahun, sehingga penggunaan batubara untuk pembangkit tersebut meningkat lebih dari dua kalinya, yaitu dari 13,72 juta ton pada 2000 menjadi 31 juta ton pada 20081). Penggunaan batubara pada pembangkit listrik tersebut diperkirakan akan meningkat sesuai dengan rencana pengoperasian PLTU (Pembangkit Listrik Tenaga Uap) baru berbahan bakar batubara yang diproyeksikan mencapai 83 juta ton batubara pada tahun 2010. Pada Juni 2008, PT. PLN (Persero) telah menanda tangani kesepakatan untuk pengembang-an 29 buah projek PLTU batubara dengan kapasitas total $8.718 \mathrm{MW}$, di luar target sebesar 9.816 MW projek kesepakatan yang telah ditanda tangani dan 9 projek (6.672 MW) yang sedang dalam tingkat konstruksi ${ }^{4}$.

Pengguna batubara yang cukup besar lainnya adalah pabrik semen, pada tahun 2008 penggunaan batubara untuk bahan bakar pabrik semen mencapai 6,84 juta ton, atau meningkat dengan pertumbuh-an rata-rata sekitar 15 persen per tahun dari tahun 2000 yang mencapai 2,23 juta ton ${ }^{1}$. Penggunaan batubara untuk pabrik semen tersebut juga diperkirakan akan meningkat terus, sesuai dengan rencana peningkatan jumlah pabrik produsen dan kapasitas ataupun rencana pembuatan pabrik baru. Semen Gresik Group merencanakan membangun 10 unit PLTU batubara baru dengan total kapasitas $410 \mathrm{MW}$ pada tahun 2010 yang meliputi pabrik-pabrik Semen Gresik di Tuban, Semen Tonasa di Makassar, Semen Padang di Padang, serta pabrik semen baru di Jawa dan Sulawesi Selatan ${ }^{4}$.

\section{DAMPAK LINGKUNGAN PENGGUNAAN BATUBARA}

Batubara merupakan bahan bakar fosil yang paling kotor, sehingga semakin meningkatnya penggunaan batubara tersebut perlu mendapat perhatian mengenai 
dampak lingkungan akibat emisi bahan pencemar (polutan) seperti $\mathrm{SO}_{2}, \mathrm{NO}_{x}$, dan SPM (Suspended Particulate Matters), maupun emisi gas rumahkaca $\mathrm{CO}_{2}$ Tingkat kekotoran batubara atau emisi bahan pencemar dari penggunaan batubara tersebut dapat diekspresikan sebagai koefisien emisi (emission coefficient) atau faktor emisi (emission factors), yaitu nilai rata-rata yang berkaitan dengan jumlah polutan dengan aktifitas teknologi energi5) seperti yang diperlihatkan pada Tabel 1 .

Tabel tersebut memperlihatkan bahwa pembangkit listrik tenaga uap yang berbahan bakar batubara (PLTU-batubara) mengeluarkan emisi-emisi $\mathrm{SO}_{2}, \mathrm{NO}_{x}$, dan SPM (Suspended Particulate Matters) paling besar dibandingkan dengan emisiemisi polutan tersebut yang dikeluarkan oleh pembangkit listrik yang berbahan bakar gas maupun minyak. Pengeluaran emisi-emisi polutan tersebut ke atmosphir diperkirakan dapat mengakibatkan pencemaran lingkungan yang langsung maupun tidak langsung dapat berakibat terhadap terganggunya ekosistem termasuk manusia dan lingkungannya.

Dampak lingkungan dari emisi polutan tersebut antara lain; emisi $\mathrm{SO}_{2}$ dipersalahkan sebagai salah satu polutan yang bertanggung jawab terhadap terjadinya hujan asam yang dapat merusak hutan dan tanaman, serta pengasaman danau dan sungai sehingga tak mampu menopang kehidupan air. Emisi $\mathrm{NO}_{\mathrm{x}}$ mempunyai kontribusi terhadap terganggunya ekosistem yang berupa sifat kimia air dan tanah yang menyebabkan kematian hewan air, serta menghambat pertumbuhan tanaman. $\mathrm{NO}_{\mathrm{x}}$ juga dapat menyebabkan penyakit yang berhubungan dengan pernafasan bagi manusia, seperti asthma, emphhysema, dan bronchitis pada manusia. Sementara itu dampak SPM bergantung pada jumlah dan komposisi kimianya, selain dapat berdampak terhadap fungsi pernafasan manusia, juga dapat berpengaruh terhadap terganggunya pertumbuhan tanaman ${ }^{5}$.
Tabel 1. Faktor Emisi dari Pembangkit Listrik Berbahan Bakar Fosil.

\begin{tabular}{|l|l|l|r|}
\hline \multirow{2}{*}{ Jenis Pembangkit } & \multicolumn{3}{|c|}{ Koefisien Emisi (ton/ } \\
\cline { 2 - 4 } & $\mathrm{SO}_{2}$ & $\mathrm{NO}_{x}$ & SPM \\
\hline PLTU-Batubara 400MW & & & \\
\hline -Batubara Bukit Asam & 4.740 & 4.560 & 731 \\
\hline -Batubara Kalimantan & 4.340 & 4.560 & 666 \\
\hline & & & \\
\hline PLTU-Batubara 600MW & & & \\
\hline - Batubara Bukit Asam & 4.360 & 4.390 & 670 \\
\hline - Batubara Kalimantan & 3.990 & 4.190 & 612 \\
\hline & & & \\
\hline PLTU -Minyak & & & \\
\hline -- Minyak bakar, & 11.700 & 2.320 & 288 \\
\hline Indonesia & & & \\
\hline & & & \\
\hline Pembangkit Listrik-Gas & & & \\
\hline - Gas combined cycle & & 1.790 & 0 \\
\hline - Gas turbine & & 2.670 & 0 \\
\hline & & & \\
\hline PLTG Minyak & & & \\
\hline - Minyak Diesel, & 2.460 & 4.560 & 104 \\
\hline Indonesia & & & \\
\hline & & & \\
\hline Gen Set Diesel & & & \\
\hline - Minyak Diesel, & 2.010 & 8.640 & 324 \\
\hline Indonesia & & & \\
\hline Sumber & & & \\
\hline
\end{tabular}

Sumber: 5).

Selain mengandung polutan, batubara juga mempunyai faktor emisi karbon (Carbon Emission Factor) yang paling tinggi di antara faktor emisi karbon dari sumber-sumber energi fosil lainnya. Tingginya faktor emisi karbon dari batubara mengindikasikan bahwa penggunaan batubara juga mengeluar-kan emisi gas rumahkaca $\mathrm{CO}_{2}$ yang tinggi. Faktor emisi karbon batubara bituminous adalah 25,8 ton carbon untuk setiap TJ (Teta $=10^{12}$ Joule) produksi energi, sedangkan faktor emisi karbon dari minyak diesel adalah 
20,2 ton karbon per TJ, dan faktor emisi gas alam adalah 15,3 ton karbon per $\mathrm{TJ}^{6}$. Peningkatan emisi gas rumahkaca $\mathrm{CO}_{2}$ di atmosfir diperkirakan akan menyebabkan terjadinya pemanasan global yang berdampak terhadap melelehnya es di kutub yang berakibat terhadap naiknya permukaan laut yang menyebabkan berkurangnya luas daratan, hilangnya pulau kecil, serta terjadinya banjir dan cuaca ekstrim ${ }^{5}$.

\section{PENGEMBANGAN TEKNOLOGI BATUBARA BERSIH.}

Berdasarkan dampak lingkungan oleh emisi gas buang dari penggunaan batubara, dan tidak terhindarinya pemanfaatan batubara untuk memenuhi kebutuhan energi yang semakin meningkat, penerapan teknologi pengurangan emisi polutan dari penggunaan batubara tersebut perlu dipertimbangkan. Teknologi tersebut biasa disebut sebagai teknologi-teknologi batubara bersih atau Clean Coal Technologies (CCT). Teknologi tersebut dapat diklasifikasikan berdasarkan tingkat proses produksi energi pada saat penerapannya, yang meliputi teknologiteknologi precombustion; combustion; dan post-combustion; serta coal conversion.

Dalam precombustion technologies, sulfur dan semua kotoran bahan pencemar dibuang sebelum batubara dibakar. Pada combustion technologies, tehnik-tehnik yang menerapkan pencegahan terjadinya emisi polutan dalam boiler ketika sedang terjadinya proses pembakaran. Sementara itu postcombustion technologies, gas buang yang ke luar dari boiler diberi perlakuan untuk dikurangi kandungan polutannya. Terahir, coal conversion, yaitu pengubahan batubara ke dalam bentuk gas atau cair yang dapat dibersihkan dan dipergunakan sebagai bahan bakar.

\subsection{Teknologi Sebelum Pembakaran (Precombustion).}

Batubara dikenal sebagai bahan bakar fosil yang kotor, sehingga sebelum dibakar atau dipergunakan, batubara tersebut perlu dicuci atau dibersihkan terlebih dahulu. Tujuan utama dari proses pencucian sebelum pembakaran tersebut adalah untuk mengurangi atau menghilangkan kotoran terutama kandungan sulfur yang secara organik tidak terikat pada batubara. Pencucian batubara tersebut juga dapat memperbaiki kandungan panas, sehingga dapat meningkatkan efisiensi pembangkitan ${ }^{3}$. Proses pembersihan batubara tersebut secara luas dapat mengurangi emisi sulfur secara berarti dari pembakaran batubara ${ }^{7}$.

Secara tradisional, teknologi pembersihan batubara sebelum pembakaran tersebut terdiri atas dua cara, yaitu pembersihan secara fisik (physical cleaning) dan pembersihan secara kimia (chemical cleaning). Sementara itu, cara baru dari teknologi pembersihan batubara tersebut adalah pembersihan batubara secara biologi (biological cleaning) yang berkembang sejalan dengan kemajuan tehnik mikroba dan enzym untuk mengeluarkan sulfur dan abu dari batubara ${ }^{7}$. Secara rinci teknologiteknologi sebelum pembakaran tersebut adalah sebagai berikut.

\subsubsection{Physical Cleaning}

Physical cleaning atau pembersihan batubara secara fisik sebelum pembakaran dilakukan dengan cara memecahkan batubara ke dalam bongkahan yang lebih kecil, kemudian batubara tersebut dipisahkan dari kotoran seperti partikelpartikel tanah, batu, dan pyrit dengan cara dicuci. Kotoran tersebut dapat dipisahkan dari batubara didasarkan pada perbedaan kerapatan atau karakteristik fisik lainnya. Proses pembersihan fisik tersebut hanya dapat membersihkan batubara dari kotoran yang secara organik atau kimia tidak terikat pada batubara seperti partikel tanah, batu, dan pyrite (pyritic sulfur). Metoda pembersihan batubara secara fisik tidak bisa menghilangkan sulfur yang secara organik terikat dengan batubara, 
juga tidak bisa membuang nitrogen dari batubara. Pembersihan batubara secara fisik diperkirakan dapat membuang 30-50\% dari pyritic sulfur dan sekitar $60 \%$ dari abu mineral dalam batubara ${ }^{3 \& 7)}$.

Sekarang ini masih sedang dikembangkan metoda pembersihan batubara secara fisik yang lebih maju yang lebih efisien. Peningkatan efisiensi dengan metoda baru tersebut dapat dicapai melalui penghancuran batubara menjadi butiran yang lebih halus lagi, sehingga lebih banyak lagi piryte dan kotoran lainnya dilepaskan dari batubara. Pemanasan batubara (coal thermal treatment) dapat dilakukan untuk mengurangi kandungan air dan memodifikasi karakteristik permukaan untuk menghindari reabsorption (penyerapan kembali). Proses tersebut diharapkan dapat memisahkan sampai 90 persen pyritic sulfur dari batubara di masa datang ${ }^{3)}$.

\subsubsection{Chemical/Biological Cleaning}

Chemica/biological cleaning adalah pembersihan batubara secara kimia maupun biologi yang dilakukan untuk menghilangkan kotoran yang terikat secara organik (organic sulfur) pada batubara. Pembersihan batubara secara kimia yang menunjukkan hasil menjanjikan adalah molten caustic leaching. Tehnik tersebut memakai suatu bahan kimia natrium atau kalium panas yang dapat melumerkan sulfur dan bahan mineral lainnya dari batubara. Sementara itu pembersihan batubara secara biologi adalah suatu cara pembersihan batubara dari kotoran organic sulfur dengan menggunakan bakteri atau enzym untuk "memakan" sulfur dalam batubara tersebut. Para ilmuwan optimis bahwa menghilangkan sulfur sampai 90 persen dapat membuat keekonomian pembersihan batubara secara biologi lebih memungkinkan di masa datang ${ }^{3 \& 7}$.

\subsection{Teknologi Selama Proses Pembakaran (Combustion).}

Pembersihan batubara pada saat pembakaran merupakan cara menghilangkan bahan pencemar dari batubara ketika batubara tersebut sedang dibakar. Hal tersebut dapat dicapai melalui pengendalian parameter pembakaran seperti bahan bakar, udara atau oksigen, dan temperatur. Beberapa tehnik dipergunakan untuk menghilang-kan emisi $\mathrm{SO}_{2}$ atau membatasi $\mathrm{NO}_{x}$ pada saat pembakaran yang secara ber-samaan dapat juga memperbaiki efisiensi panas.

\subsubsection{Furnace Sorbent Injection (FSI).}

FSI adalah suatu teknik sederhana untuk menghilangkan sulfur melalui penginjeksian bahan penghisap (sorbent) seperti kapur ke dalam tungku (furnace) pembakaran batubara, sehingga hasilnya bereaksi untuk membentuk calsium sulfat $\left(\mathrm{CaSO}_{4}\right)$ yang kemudian dikumpulkan bersama abu terbang (fly ash) di dalam alat pengendalian partikel. FSI dengan penginjeksian kapur tersebut dapat menghilangkan 35 sampai dengan $55 \% \mathrm{SO}_{2}{ }^{3}$.

Masalah utama dalam pengembangan teknologi ini secara komersial antara lain pengelolaan jumlah reaktif, tingginya limbah alkaline (sorben yang bercampur dengan abu); serta dampak dari tambahan jumlah limbah dan perubahan karakteristik flue gas pada peralatan pengendalian partikel. Peralatan tersebut dapat ditingkatkan unjuk kerjanya dengan menggunakan humidification (pelembaban) dari campuran flue-gas dan sorbent. Keuntungan utama cara FSI adalah rendahnya biaya investasi (capital cost), yaitu sekitar US \$60 sampai US $\$ 100$ per kilowatt. Namun biaya keseluruhan pembuangan sulfur dengan cara ini lebih tinggi daripada biaya yang sama melalui flue gas desulfurization (FGD) atau clean coal technology lainnya ${ }^{3)}$.

\subsubsection{Atmospheric Fluidized Bed Combustion (AFBC).}

AFBC adalah suatu teknologi yang maju untuk boiler pada sektor industri 
(dengan kapasitas pembangkitan 10 sampai dengan $25 \mathrm{MW}$ ). Sekarang ini teknologi tersebut sedang dikembangkan untuk boiler utilitas yang membangkitkan 75 sampai dengan $350 \mathrm{MW}$. Beberapa unit teknologi ini masih sedang dikembangkan dalam skala demonstrasi di Amerika Serikat.

Proses ini dapat mengurangi pembentukan $\mathrm{NO}_{x}$ dan membuang sampai 90 persen emisi $\mathrm{SO}_{2}$. Namun sebagaimana FSI, AFBC juga menghasilkan limbah tambahan yang sulit untuk ditangani dalam peralatan pengendalian partikel yang ada. Sementara itu biaya investasi teknologi AFBC masih sangat mahal, yaitu sekitar US $\$ 1500$ per kilowatt ${ }^{3)}$.

\subsubsection{Pressurized Fluidized Bed Combustion (PFBC).}

PFBC mempunyai prinsip yang sama dengan $A F B C$, kecuali boilernya dioperasikan di bawah tekanan 10 atmosfir. Peningkatan energi dari gas yang ke luar dapat menggerakan gas turbin maupun steam turbin, potensial mendorong efisiensi pembangkitan sampai lebih dari 40 persen Pengembangan system tersebut dengan menggunakan advance cycle diharapkan dapat meningkatkan efisiensi energi di atas 45 persen $^{3}$.

Unit kecil PFBC cocok dibangun pada daerah yang mempunyai keterbatasan ruang lokasi dan pengaturan konstruksi. PFBC masih dikembangkan dalam taraf demonstrasi, seperti pengembangan PFBC dengan kapasitas terpasang antara 70 sampai dengan 80 MW di Swedia, Spanyol, dan USA ${ }^{3)}$. Jepang sudah mulai membangun PFBC dengan unit kapasitas yang lebih besar lagi, yaitu $360 \mathrm{MWe}$ di Karita, dan 250 MWe di Osaki²). Teknologi PFBC tersebut juga dapat dikatakan masih terhitung mahal dengan biaya investasi sekitar US $\$ 1400$ per kilowatt ${ }^{3)}$.

\subsection{Teknologi Sesudah Proses Pembakaran (Postcombustion).}

Semua teknologi-teknologi baru yang diterapkan sesudah proses pembakaran seperti pembersihan gas untuk mengurangi emisi-emisi $\mathrm{SO}_{2}$ dan $\mathrm{NO}_{x}$, serta partikel debu (pada beberapa kasus) secara simultan dari cerobong masih sedang dikembangkan. Teknologi-teknologi batubara bersih tersebut antara lain sebagai berikut.

\subsubsection{Flue-gas Desulfurization (FGD).}

Tehnik FGD menggunakan kapur atau batu kapur sebagai alkaline sorbent untuk "menggosok" $\mathrm{SO}_{2}$ dari emisi pada utililitas. Pada "FGD basah", sorbent terdapat dalam slurry yang berhubungan dengan flue gas dalam bejana reaksi di bagian bawah alat pengendalian partikel. Gas yang bersih mengalir dan biasanya harus dipanaskan kembali sebelum dilepas ke atmosfir untuk mengurangi karat pada cerobong dan memperoleh dispersi yang paling halus. Sementara itu, pada "FGD kering", bejana reaksi ditempatkan pada bagian atas alat pengendali partikel. Slurry kapur mengering sebagai reaksi dengan gas cerobong yang panas, dan hasil cairan dikumpulkan pada bejana reaksi dan dalam alat pengendali partikel.

Perbaikan tehnik FGD seperti jet bubbling reactor yang dipergunakan dalam proses Chiyoda CT-121 untuk dipergunakan di lokasi ruang yang terbatas sudah mencapai 90 sampai dengan 95 persen pembuangan $\mathrm{SO}_{2}$. Biaya investasi sistem FGD ini bervariasi antara lain bergantung kandungan sulfur dan ukuran boiler. Biaya investasi (retrofit pada pembangkit berkapasitas $300 \mathrm{MW}$ ) dari FGD konvensional diperkirakan berkisar antara US \$170-250 per kilowatt. Perbaikan sistem ini telah menghemat 20 sampai dengan 50 persen dari biaya investasi dan 20 sampai 40 persen dari biaya operasi dari sistem FGD konvensional ${ }^{3)}$.

\subsubsection{Regenerable Flue-gas Desulfurization Systems.}

Sistem ini menggunakan berbagai macam prinsip fisik dan kimia dan umumnya 
memperoleh sulfur hasil samping (yang terbuang) sebagai konsentrat $\mathrm{SO}_{2}$, asam sulfur, atau elemen sulfur. Pemanfaatan hasil samping $\mathrm{SO}_{2}$ tersebut sebagian dapat dikonpensasikan untuk tingginya biaya investasi dari regenerable FGD. Keuntungan utama dari system ini adalah tidak adanya produksi limbah dan sedikit limbah cair, serta sedikitnya bahan penghisap (sorbent) yang dibutuhkan. Meskipun .proses tersebut dapat mencapai efisiensi pembuangan $\mathrm{SO}_{2}$ sampai 95 persen, tapi system tersebut memerlukan biaya kapital atau investasi yang tinggi, yaitu 30 sampai 50 persen lebih tinggi daripada biaya system FGD konvensional ${ }^{3)}$.

\subsubsection{Selective Catalytic Reduction (SCR).}

Teknik ini menjadi pusat perhatian sebagian besar penelitian dan demonstrasi pengendalian $\mathrm{NO}_{x}$ setelah pembakaran. Tehnik ini mempergunakan ammonia, sebagai zat pengurang (reducing agent) yang diinjeksikan ke aliran gas di cerobong dalam suatu katalist antara boiler dan pemanas udara. Tehnik SCR tersebut dapat mengurangi emisi $\mathrm{NO}_{x}$ di atas 80 sampai dengan 90 persen. Pemasangan SCR pada PLTU batubara di Jepang dan Eropa dapat membuang 60 sampai 80 persen dari $\mathrm{NO}_{x}$. dan meninggalkan residu emisi ammonia lebih kecil dari 5 ppm. Biaya investasi system ini di Eropa diperkirakan rata-rata US \$125 per kilowatt. Biaya tersebut relatif sama dengan perkiraan EPRI (Electric Power Research Institute) di Amerika Serikat, yaitu antara US \$100 sampai dengan US \$125 per kilowatt. Sementara itu, biaya operasi system SCR di Amerika Serikat maupun Jepang diperkirakan antar 0,4 sampai 0,9 cent dollar per kilowatt hour ${ }^{3)}$.

\subsection{Konversi Batubara.}

Teknologi batubara bersih lainnya adalah teknologi konversi batubara yang mengubah terlebih dahulu batubara dari bentuk padat ke bentuk lainnya seperti gas, maupun cair. Teknologi-teknologi tersebut masih dalam taraf percobaan dan pengembangan. Teknologi-teknologi pengembangan proses konversi batubara tersebut antara lain sebagai berikut.

\subsubsection{Integrated Gasification Combined Cycle (IGCC).}

IGCC merupakan teknologi pembangkit listrik batubara yang ramah lingkungan. Teknologi tersebut merupakan kombinasi gasifikasi batubara yang terintegrasi yang merupakan paduan dua tahapan proses, yaitu teknologi gasifikasi batubara (coal gasification) yang menggunakan batubara untuk membuat gas sintetis (syngas); dan teknologi combined cycle yang merupakan methode paling efisien untuk memproduksi listrik. Pertama, gasifikasi batubara mengubah batubara ke bentuk gas melalui oksidasi parsial. Gas tersebut dikenal sebagai gas sintesis atau syngas yang terdiri atas karbon monoksida ( $\mathrm{CO}$ ) dan hydrogen. Gas tersebut didinginkan dan komponen yang tidak diinginkan seperti karbon dioksida $\left(\mathrm{CO}_{2}\right)$ serta sulfur dibuang

Pada tahapan kedua, gas yang telah bersih dari kotoran tersebut dibakar dalam gas turbine konvensional untuk memproduksi energi listrik, dan gas buang panas yang diperoleh diperguna-kan untuk mendidihkan air, sehingga diperoleh uap untuk turbine uap yang juga memproduksi energi listrik. Secara umum IGCC mempunyai beberapa keuntungan, antara lain; dapat meningkatkan efisiensi panas hampir 50 persen yang berakibat pada penghematan pasokan bahan bakar dan rendahnya emisi polutan $\mathrm{SO}_{\mathrm{x}}$ dan $\mathrm{NO}_{\mathrm{x}}$, maupun emisi gas rumahkaca $\mathrm{CO}_{2}$, serta berkurangnya produksi limbah padat. Oleh karena itu, IGCC dapat mengurangi sampai 99 persen sulfur, dan emisi NOx sampai di bawah 50ppm 8).

Beberapa unit demontrasi dari IGCC, sebagian besar berkapasitas 250 MWe 
sudah beroperasi di Eropa dan Amerika Serikat, yaitu IGCC yang berkapasitas 235 MWe di Buggenum, Belanda yang mulai beroperasi pada tahun 1993 dan IGCC yang berkapasitas 330 MWe di Puertollano, Spanyol. Sementara itu IGCC plant di Amerika Serikat terdapat di Wabash River, Indiana; Polk Power dekat Tampa, Florida, dan Pinon Pine, Nevada ${ }^{9}$. Skala demontrasi unit IGCC plant lainnya di Amerika Serikat adalah IGCC yang berkapasitas 100 MW di Cool Water, California yang telah selesai dibangun sejak tahun $1989{ }^{6}$ ). Selain itu, sejak September 2007 Jepang juga sudah mengoperasikan unit demontrasi IGCC yang berkapasitas $250 \mathrm{MW}$ di Nakaso ${ }^{9}$.

Berdasarkan US Coal, American Energy Review 2005, biaya investasi dari IGCC tersebut masih mahal, diperkirakan mencapai US\$1,6 juta per megawatt kapasitas, dibandingkan dengan biaya investasi untuk pembangkit listrik batubara konvensional yang hanya US \$1 juta per megawatt kapasitas ${ }^{10)}$. Perkiraan tersebut tidak berbeda dengan perkiraan Electrical Power Research Institute (EPRI) di Amerika Serikat, yaitu US \$1610 per kilowatt ${ }^{11)}$.

\subsubsection{Integrated Gasification Fuel Cell (IGFC)}

Teknologi ini menggunakan gas sintetis (syngas) yang diproduksi oleh gasifier untuk menggerakan molten carbonate fuel cell untuk turbine pembakaran, sehingga mampu berpotensi meningkatkan seluruh efisiensi di atas 45 persen. Bersama gas pembakaran panas yang bersih, perpaduan kimia dan panas yang oprtimal dari fuel cell dan catalytic gasifier dapat meningkatkan efisiensi pembangkitan lebih tinggi lagi bahkan bisa mencapai lebih dari 55 sampai dengan 60 persen. Oleh karena itu, teknologi tersebut akan memerlukan gasification dan pembersihan gas pada temperature mendekati temperature pengoperasian $1.300^{\circ} \mathrm{F}\left(704^{\circ}\right.$ C) dari molten carbonate ${ }^{6)}$. Teknologi ini masih dalam skala pilot plant seperti yang dilakukan oleh Wakamatsu Laboratory, Technology Development Center of Electric Power Development Co. Ltd., di Jepang ${ }^{12)}$. Biaya investasi IGFC tersebut diperkirakan antara US \$1443 sampai dengan US \$1667 per kilowatt ${ }^{13)}$.

\section{KESIMPULAN}

- Kebutuhan energi dari tahun ke tahun semakin meningkat,. Sebagian besar dari kebutuhan energi tersebut dipenuhi oleh minyak, sedangkan sisanya dipenuhi oleh sumber energi lainnya yaitu batubara, biomasa, gas alam, tenaga air, dan panas bumi.

- Berdasarkan ketersediaan sumber-nya, batubara merupakan sumber energi yang paling potensial untuk menggantikan peranan minyak sebagai sumber energi yang utama untuk pembangkit listrik dan sektor industri.

- Semakin meningkatnya penggunaan batubara diperkirakan akan menyebabkan semakin meningkat pula emisi polutan (bahan pencemar) seperti $\mathrm{SO}_{2}, \mathrm{NO}_{x}$, dan partikel debu, maupun emisi gas rumahkaca $\mathrm{CO}_{2}$ yang dapat berdampak negatif terhadap lingkungan, yang meliputi antara lain terganggunya kesehatan manusia, kerusakan ekosistem, dan pemanasan global (global warming).

- Pengembangan teknologi batubara bersih (Clean Coal Technologies) dalam pemanfaatan batubara perlu dipertimbangkan, sehingga sumber energi batubara dapat dimanfaatkan secara optimal pada masa mendatang tanpa kekhawatiran terjadinya peningkatan emisi polutan dan gas rumahkaca yang berdampak negatif terhadap lingkungan.

- Sebagian besar dari tantangan dari pengembangan teknologi batubara bersih terletak pada komersialisasi teknologi 
tersebut, sehingga penggunaan batubara masih tetap dapat bersaing secara ekonomi meskipun harus dikeluarkan biaya untuk menghilangkan emisi polutan maupun emisi gas rumahkaca.

\section{DAFTAR PUSTAKA}

1. -------- (2009). Handbook of Energy \& Economic Statistics of Indonesia 2009. Center for Data and Information on Energy and Mineral Resources. Ministry Energy and Mineral Resources.

2. - ------ (2009). Clean Coal Technologies. International Energy Agency (IEA), Clean Coal Center. London, UK. (www.iea-coal. org).

3. Torrens, I.M. (1990). Developing Clean Coal Technologies,- 'Environment' July/ August 1990, Volume 32. Number 6.

4. ------- (2009). Indonesia Coal Book 2008/2009. Petromindo. Asosiasi Pertambangan Batubara Indonesia.

5. ------- (1993). Environmental Impacts of Energy Strategies for Indonesia. Final Summary Report. Indonesian-German Research Project. Badan Pengkajian dan Penerapan Teknologi (BPPT) Forschungszentrum Juelich $\mathrm{GmbH}$ (KFA). May 1993.
6. ----(1966). Greenhouse Gas Inventory Workbook. Revised 1996 IPCC Guidelines for National Greenhouse Gas Inventories. Volume 2. Edited by J.T. Houghton, L.G.Meira Filho, B. Lim, K. Treanton, I. Mamaty, Y. Bonduki, D.J. Griggs and B.A. Callander.

7. Speight, J.G. (1994). The Chemistry and Technology of Coal. CD \& W Inc., Laramie, Wyoming USA. ISBN 0-82477200-9.

8. Simento, N. (2008). IGCC Power Generation.(www.ccsd.biz).

9. http://sangfuehrer.blogspot.com.

10.http://go2alam.wordpress.com

11. Dalton, S. 2004. Cost Comparison IGCC and Advanced Coal. EPRI (Electric Power Research Institute, Inc). Roundtable on Deploying Advanced Clean Coal Plants. July 29, 2004.

12.Sotooka, M. 2003. Coal Gasification Technology (II)-Coal Energy Application for Gas, Liquid and Electricity (EAGLE). The Japan Institute of Energy, Vol.82, No. 11, November 2003.

13. Grol, E; J. DiPietro; J.H.J.S. Thijssen; W.Surdoval; H. Quedenfeld. 2007. The Benefits of SOFC (Solid-Oxide Fuel Cell) for Coal-Based Power Generation. National Energy Technology Laboratory (NETL). Oct. 30, 2007. (www.netl.doe.gov.). 